\title{
Prevalence of C-Shape Canal in Mandibular Second Molar in South Indian Population
}

Research Article

Joshini Shanmugam ${ }^{1}$, Surendar Sugumaran ${ }^{2 *}$, Suresh $V^{3}$

${ }^{1}$ Saveetha Dental College and Hospitals, Saveetha Institute of Medical and Technical Sciences, Saveetha University, Chennai, India.

${ }^{2}$ Senior Lecturer, Department of Conservative Dentistry and Endodontics, Saveetha Dental College and Hospitals, Saveetha Institute of Medical and Technical Sciences, Saveetha University, Chennai, India.

${ }^{3}$ Reader, Department of Prosthodontics, Saveetha Dental College and Hospitals, Saveetha Institute of Medical and Technical Sciences, Saveetha University, Chennai, India.

\section{Abstract}

Unusual root canal anatomy always poses a diagnostic and treatment challenge. Identification of such variation is important for the success of root canal treatment outcome. C-shape canal is such an aberrant morphology of molar teeth that vary in different population. Thus, knowledge of racial predilection of $\mathrm{C}$-shape canal configuration in different population for early diagnosis is obligatory. The aim of this study was to assess the prevalence of $\mathrm{C}$-shape canal in mandibular second molar. Case records of patients who visited the department of Conservative Dentistry and Endodontics at Saveetha Dental College from June 2019 to March 2020. 475 patients who fulfilled the inclusion and exclusion criteria were included in the study. The data was analysed through chi square. It was observed that C-shape canal was prevalent in the mandibular second molar. Out of 475 patients, $5.89 \%$ were reported with $\mathrm{C}$-shape canal in the mandibular second molar with maximum prevalence in the age group 14-34 years and slightly more in females than males $(\mathrm{p}>0.05)$. Within the limitations of this study, it was concluded that $\mathrm{C}$-shape canal is less prevalent when compared to normal canal anatomy in mandibular second molar.

Keywords: C-Shape Canal; Canal Variation; Mandibular Second Molar.

\section{Introduction}

In endodontics, root canal treatment of a tooth with variable anatomy is a rule rather than an exception $[1,2]$. One such anatomic variation is the $\mathrm{C}$-shaped root canal system, although most commonly seen in mandibular second molars have also been observed in mandibular premolars, maxillary first molars, and maxillary and mandibular third molars [3, 5]. Historically, various authors have done numerous investigations on the prevalence and ethnic variation of such canal systems $[6,7]$. Initially, named as "gutter-" shaped canals by Nakayama and horseshoe reduction forms, the term $\mathrm{C}$ shaped was originally described by Cooke and Cox in endodontic literature in the year 1979 [8-10]. Manning postulated that the reason for the occurrence of C-shape canal was the failure of hertwig's epithelial root sheath to fuse. It is usually characterized by presence of a fin or wels connecting the individual mesial and distal canals having $\mathrm{C}$-shape axial section
[11-14]. Roots containing C-shape canals often have a square or conical shape configuration $[15,16]$.

The main goal of endodontic therapy is to prevent or heal apical periodontitis, this means cleaning, shaping, disinfection and three-dimensional obturation of the root canal system $[17,18]$. Many early and recent studies showed that a root with single tapering canal is an exception rather than the rule [19-22].

The complexity of the root canal anatomy presents clinical challenges during the treatment, so knowledge of pulpal anatomy and its variations are essential for long term success of endodontic treatments [23-26].

C-shape canals are among these variations that were first described by cooke and cox $[9,27]$. The name comes from C-shape cross sectional morphology of the root and root canal. In such cases,

*Corresponding Author:

Surendar Sugumaran,

Senior Lecturer, Department of Conservative Dentistry and Endodontics, Saveetha Dental College and Hospitals, Saveetha Institute of Medical and Technical Sciences, Saveetha University, Chennai, India.

Tel: 9791183388

E-mail: surendars.sdc@saveetha.com

Received: October 07, 2020

Accepted: November 22, 2020

Published: November 27, 2020

Citation: Joshini Shanmugam, Surendar Sugumaran, Suresh V. Prevalence of C-Shape Canal in Mandibular Second Molar in South Indian Population. Int J Dentistry Oral Sci. 2020;7(11):1103-1106. doi: http://dx.doi.org/10.19070/2377-8075-20000219

Copyright: Surendar Sugumaran ${ }^{\circ} 2020$. This is an open-access article distributed under the terms of the Creative Commons Attribution License, which permits unrestricted use, distribution and reproduction in any medium, provided the original author and source are credited. 
several discrete orifices are not seen, instead, the pulp chamber has a single ribbon shaped orifice with 189 degree arc- In mandibular molars, the arc originates from the mesiolingual line angle, continues towards buccal and terminates at the distal aspect of pulp chamber [28].

The variation of C-shape root canal system appears to be genetically determined, and it has some relationship with ethnic origin6. It could be found throughout the world but the incidence is much higher in Asian population [29-31]. Incidence studies have been reported in Chinese, Indian, and Iranian population, with the highest frequency being reported in the Chinese population $(29.7 \%)$ in case of mandibular premolars. The C-shaped canal anatomy has also been reported in maxillary first molars $(0.12 \%)$, maxillary third molars $(4.7 \%)$, mandibular third molars $(3.5 \%$ $4 \%$ ), and mandibular second premolars (1\%) [32].

The objective of this study is to assess the prevalence of C-shape canal variation in mandibular second molar in the south indian population.

\section{Materials And Methods}

The study was undertaken after ethical approval was obtained from the institutional review boards. Data was retrospectively collected from the case records patients who visited the Department of Conservative Dentistry and Endodontics at Saveetha Dental College. Patients who had undergone root canal treatment in mandibular second molar were included in the study. Patients who were undergoing root canal treatment in teeth other than 37 and 47 were excluded from the study. 5000 plus case sheets of patients who underwent root canal treatment were reviewed and from that, 475 patients who fulfilled the criteria were included in the study. Simple random sampling was done to minimise the sampling bias. Data verification was done based on the age, gender, teeth number, canal variation. Data was entered in the excel sheet in a methodical manner and was imported to SPSS. Incomplete or uncensored data was excluded from the study. IBM SPSS 20.0 Software was used for data analysis. Independent variables include - age, gender and dependent variables include canal variation and teeth number. Descriptive and inferential statistics was used. Inferential test includes the chi-square test.

\section{Results And Discussion}

Out of 475 patients who underwent root canal treatment in mandibular second molar, 5.89\% were reported to have C-shape canal [figure-1] with maximum prevalence in the age group 14-34 years and slightly more in females than males. Coming to the age group, the maximum number of patients with $\mathrm{C}$-shape canal is 14-34years $(2.95 \% ; n=14)$ followed by $35-54$ years $(2.74 \% ; n=13)$ and least in $55-74 y e a r s(0.21 \% ; n=1)$. [figure-2]. Figure 3 shows the gender distribution of $\mathrm{C}$-shape canal. Out of 475 patients, $55.5 \%$ were males and $44.5 \%$ were females where C-shape canal was prevalent in females $(3.58 \% ; \mathrm{n}=17)$ than in males $(2.32 \% \% ; \mathrm{n}=11)$. Hence, when comparing both the genders, it was observed that females were slightly more prevalent for $\mathrm{C}$-shape canal variation than males. While observing distribution of C-shape canal in left and right lower second molar, it was seen that $\mathrm{C}$-shape canal variation was prevalent in 47 (left side) $(3.16 \% ; n=15)$ than in 37 (right side) $(2.74 \% \% ; n=13)$.

The data for this retrospective study was based on south indian residents in seeking treatment at Saveetha Dental College. Currently there are no existing studies investigating the prevalence of C-shape canal anatomy in mandibular second molar in South

Figure 1. Bar chart depicts the distribution of C-shape canal and normal canal anatomy in mandibular second molar where majority have reported with normal canal anatomy(blue), followed by C-shaped canal(Green).

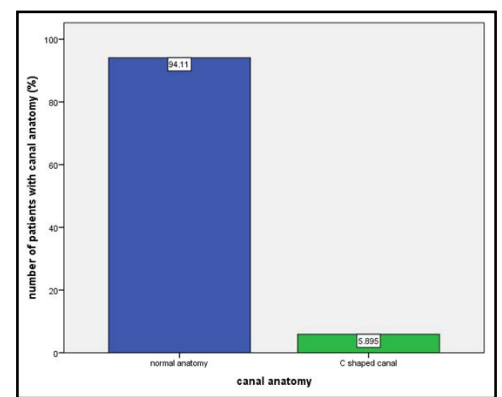

Figure 2. bar chart depicts distribution of canal anatomy in mandibular second molar according to age group. $\mathrm{X}$-axis represents the age group and $\mathrm{Y}$-axis represents the number of patients with canal anatomy. It shows that $\mathrm{C}$-shape canal (green) is most prevalent in 14-34years followed by 35-54 years and least in 55-74years. Using chi-square test $p$ value $=0.239(>0.05)$ is statistically non significant.

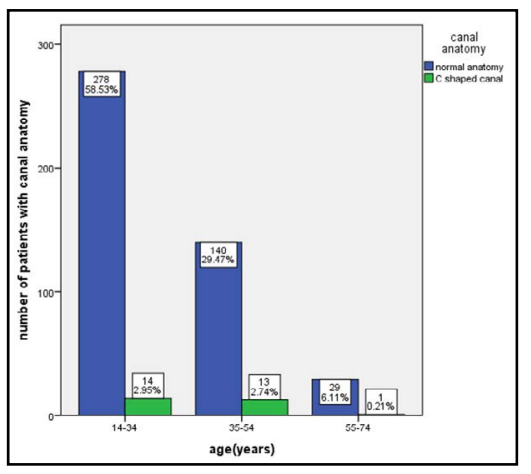


Figure 3. Bar chart depicts the association between gender and canal anatomy in mandibular second molar. $\mathrm{X}$-axis represents gender and $\mathrm{Y}$-axis represents canal anatomy. Blue bar represents normal canal anatomy and green bar represents C-shape canal. Graph 3 shows that the $\mathrm{C}$-shape canal was prevalent in females than in males. Using the chi-square test, $\mathrm{p}$ value $=0.074(>0.05)$ is statistically non significant.

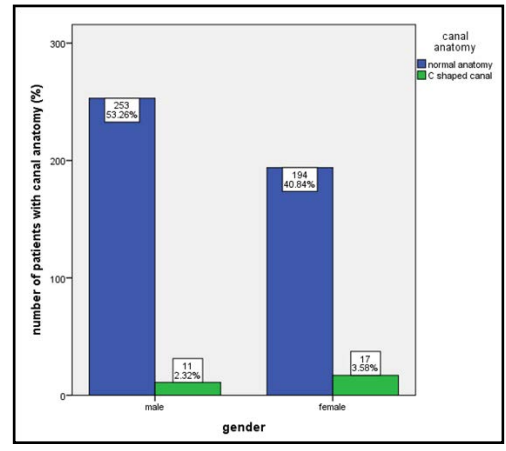

Figure 4. Bar chart depicts the association between teeth number and canal anatomy in mandibular second molar. $\mathrm{X}$-axis represents teeth number i.e right lower second molar(37) and left lower second molar(47); and Y-axis represents number of patients with canal anatomy. Blue bar represents normal canal anatomy and green bar represents C-shape canal. Graph 4 shows that C-shape canal(green) was prevalent in 47 (left side) than in 37(right side) Using the chi-square test, $\mathrm{p}$ value= $0.096>0.05$ is statistically non-significant

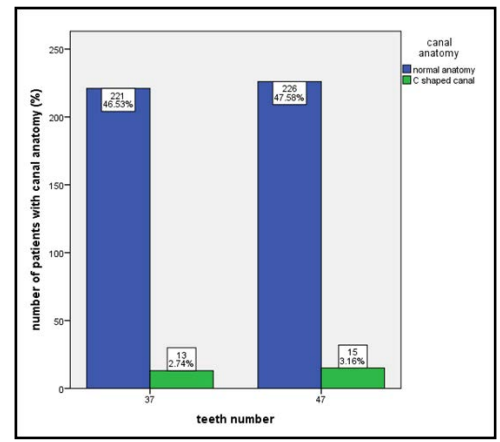

India. Since all the data available was included without a sorting process, no bias was accepted in selection of patients. The current study aims to shed light on the current scenario of prevalence of root canal therapy in $\mathrm{C}$-shape canal so that different treatment approaches can be introduced. The severity of $\mathrm{C}$-shape canal can be understood from the study.

A high incidence of C-shaped roots and root canal system in mandibular second molars has been reported in several studies conducted on japanese [33], chinese [34, 35], lebanese [36], korean [31], thai [37] populations all revealing higher prevalence of C-shape canal configuration among asians. The findings of this study differ from study conducted in Portugese population where the higher prevalence of C-shaped anatomy was found among 4554 years group with $11.1 \%$ [38] whereas the maximum prevalence of C-shape canal was seen in 14-34 years in the present study. However, the prevalence $\mathrm{C}$-shape canal in mandibular second molar very according to the region of the globe.

No statistical difference was seen in the distribution of C-shape canal between gender, and between molars on the left and right side of the mandible. These results are also in agreement with a similar work done in Chinese population [39].

A study done by Wadhwani.S [40] et.al shows that prevalence of C-shape canal in mandibular second molar is $9.7 \%$ in North Indian population whereas in the present study, the prevalence of C-shape canal in mandibular second molar is $5.8 \%$ in South indian population. This statistical difference can be due to limited sample size.
This study has some other limitations too that may have affected the results. For example, the data collection period could have been longer, different populations could have been taken for comparison.

Despite the high prevalence of C-shape canal, not all dentists are confident in approaching this variation. The current study shows that despite its drawbacks C-shape canal variation is prevalent in mandibular second molar in patients in Chennai. This suggests the need to spread awareness among dentists in India to obtain knowledge on C-shape canal and use different treatment modalities. Extensive research can be done further by observing the prevalence of different levels of $\mathrm{C}$-shape canal in different populations.

\section{Conclusion}

Within the limitations of this study, it was found that $94.11 \%$ of the population has normal canal anatomy and the prevalence of C-shape canal was only $5.8 \%$ in the mandibular second molar. C-shape canal was more prevalent in the age group 14-34 years when compared to other age groups and slightly more in females than males $(p>0.05)$ in the south indian population. Considering the drawbacks of this study, it can be concluded that there exists a need for more extensive research to be done in this area to spread awareness among dentists and develop their knowledge on this canal variation and help them understand it's severity. 


\section{Acknowledgement}

This research was supported by Saveetha Dental College and Hospital. We thank the department of Conservative Dentistry and Endodontics, Saveetha dental college for providing insight and expertise that greatly assisted this research.

\section{References}

[1]. Ramamoorthi S, Nivedhitha MS, Divyanand MJ. Comparative evaluation of postoperative pain after using endodontic needle and EndoActivator during root canal irrigation: A randomised controlled trial. Aust Endod J. 2015 Aug; 41(2): 78-87. PMID: 25195661.

[2]. Ramanathan S, Solete P. Cone-beam Computed Tomography Evaluation of Root Canal Preparation using Various Rotary Instruments: An in vitro Study. J Contemp Dent Pract. 2015 Nov 1; 16(11): 869-72. PMID: 26718293.

[3]. Baisden MK, Kulild JC, Weller RN. Root canal configuration of the mandibular first premolar. J Endod. 1992 Oct; 18(10): 505-8. PMID: 1289476.

[4]. Yu X, Guo B, Li KZ, Zhang R, Tian YY, Wang H, et al. Cone-beam computed tomography study of root and canal morphology of mandibular premolars in a western Chinese population. BMC Med Imaging. 2012 Jul 20; 12: 18. PMID: 22817397.

[5]. Basrani B. Endodontic irrigation: Chemical disinfection of the root canal system. Springer; 2015 Jul 17

[6]. Fan B, Cheung GS, Fan M, Gutmann JL, Bian Z. C-shaped canal system in mandibular second molars: Part I--Anatomical features. J Endod. 2004 Dec; 30(12): 899-903. PMID: 15564874.

[7]. Siddique R, Sureshbabu NM, Somasundaram J, Jacob B, Selvam D. Qualitative and quantitative analysis of precipitate formation following interaction of chlorhexidine with sodium hypochlorite, neem, and tulsi. J Conserv Dent. 2019 Jan-Feb; 22(1): 40-47. PMID: 30820081.

[8]. TRATMAN EK. A comparison of the teeth of people; Indo-European racial stock with the Mongoloid racial stock. Dent Rec (London). 1950 Mar; 70(3): 63-88. PMID: 24537074.

[9]. Cooke HG 3rd, Cox FL. C-shaped canal configurations in mandibular molars. J Am Dent Assoc. 1979 Nov; 99(5): 836-9. PMID: 290680.

[10]. 10. Rajakeerthi R, Ms N. Natural Product as the Storage medium for an avulsed tooth-A Systematic Review. Cumhuriyet Dental Journal. 2019; 22(2): 249-56

[11]. Manning SA. Root canal anatomy of mandibular second molars. Part I. Int Endod J. 1990 Jan; 23(1): 34-9. PMID: 2391179

[12]. Rajendran R, Kunjusankaran RN, Sandhya R, Anilkumar A, Santhosh R, Patil SR. Comparative Evaluation of Remineralizing Potential of a Paste Containing Bioactive Glass and a Topical Cream Containing Casein Phosphopeptide-Amorphous Calcium Phosphate: An in Vitro Study. Pesquisa Brasileira em Odontopediatria e Clínica Integrada. 2019; 19.

[13]. Hussainy SN, Nasim I, Thomas T, Ranjan M. Clinical performance of resinmodified glass ionomer cement, flowable composite, and polyacid-modified resin composite in noncarious cervical lesions: One-year follow-up. J Conserv Dent. 2018 Sep-Oct; 21(5): 510-515. PMID: 30294112.

[14]. Kumar D, Antony S. Calcified Canal and Negotiation-A Review. Research Journal of Pharmacy and Technology. 2018; 11(8): 3727-30.

[15]. Ravinthar K. Recent advancements in laminates and veneers in dentistry. Research Journal of Pharmacy and Technology. 2018; 11(2): 785-7.

[16]. Noor S. Chlorhexidine: Its properties and effects. Research Journal of Pharmacy and Technology. 2016; 9(10): 1755-60.

[17]. Schilder H. Filling root canals in three dimensions. Dent Clin North Am. 1967 Nov; 723-44. PMID: 5262492

[18]. Schilder H. Cleaning and shaping the root canal. Dent Clin North Am. 1974 Apr; 18(2): 269-96. PMID: 4522570

[19]. Rahimi S, Shahi S, Lotfi M, Zand V, Abdolrahimi M, Es'haghi R. Root canal configuration and the prevalence of C-shaped canals in mandibular second molars in an Iranian population. J Oral Sci. $2008 \mathrm{Mar}$; 50(1): 9-13. PMID: 18403877

[20]. Chai WL, Thong YL. Cross-sectional morphology and minimum canal wall widths in C-shaped roots of mandibular molars. J Endod. $2004 \mathrm{Jul}$; 30(7): 509-12. PMID: 15220648.

[21]. Teja KV, Ramesh S, Priya V. Regulation of matrix metalloproteinase-3 gene expression in inflammation: A molecular study. J Conserv Dent. 2018 NovDec; 21(6): 592-596. PMID: 30546201.

[22]. Janani K, Palanivelu A, Sandhya R. Diagnostic accuracy of dental pulse oximeter with customized sensor holder, thermal test and electric pulp test for the evaluation of pulp vitality: an in vivo study. Brazilian Dental Science. 2020 Jan 31; 23(1): 8-p.

[23]. Sponchiado EC Jr, Ismail HA, Braga MR, de Carvalho FK, Simóes CA. Maxillary central incisor with two root canals: a case report. J Endod. 2006 Oct; 32(10): 1002-4. PMID: 16982283.

[24]. Cleghorn BM, Christie WH, Dong CC. Root and root canal morphology of the human permanent maxillary first molar: a literature review. J Endod. 2006 Sep; 32(9): 813-21. PMID: 16934622.

[25]. Jose J, Subbaiyan H. Different Treatment Modalities followed by Dental Practitioners for Ellis Class 2 Fracture-A Questionnaire-based Survey. The Open Dentistry Journal. 2020 Feb 18; 14(1).

[26]. Teja KV, Ramesh S. Shape optimal and clean more. Saudi Endodontic Journal. 2019 Sep 1; 9(3): 235.

[27]. Manohar MP, Sharma S. A survey of the knowledge, attitude, and awareness about the principal choice of intracanal medicaments among the general dental practitioners and nonendodontic specialists. Indian J Dent Res. 2018 Nov-Dec; 29(6): 716-720. PMID: 30588997.

[28]. Nandakumar M, Nasim I. Comparative evaluation of grape seed and cranberry extracts in preventing enamel erosion: An optical emission spectrometric analysis. J Conserv Dent. 2018 Sep-Oct; 21(5): 516-520. PMID: 30294113.

[29]. Al-Fouzan KS. C-shaped root canals in mandibular second molars in a Saudi Arabian population. Int Endod J. 2002 Jun; 35(6): 499-504. PMID: 12190906.

[30]. Seo MS, Park DS. C-shaped root canals of mandibular second molars in a Korean population: clinical observation and in vitro analysis. Int Endod J. 2004 Feb; 37(2): 139-44. PMID: 14871181.

[31]. Jin GC, Lee SJ, Roh BD. Anatomical study of C-shaped canals in mandibular second molars by analysis of computed tomography. J Endod. 2006 Jan; 32(1): 10-3. PMID: 16410060.

[32]. Zhang R, Wang H, Tian YY, Yu X, Hu T, Dummer PM. Use of cone-beam computed tomography to evaluate root and canal morphology of mandibular molars in Chinese individuals. Int Endod J. 2011 Nov; 44(11): 990-9. PMID: 21658074.

[33]. Kotoku K. Morphological studies on the roots of Japanese mandibular second molars. Shikwa Gakuho. 1985 Jan; 85(1): 43-64. PMID: 3859014.

[34]. Walker RT. Root form and canal anatomy of mandibular second molars in a southern Chinese population. J Endod. 1988 Jul; 14(7): 325-9. PMID: 3251992.

[35]. Yang ZP, Yang SF, Lin YC, Shay JC, Chi CY. C-shaped root canals in mandibular second molars in a Chinese population. Endod Dent Traumatol. 1988 Aug; 4(4): 160-3. PMID: 3267526.

[36]. Haddad GY, Nehme WB, Ounsi HF. Diagnosis, classification, and frequency of C-shaped canals in mandibular second molars in the Lebanese population. J Endod. 1999 Apr; 25(4): 268-71. PMID: 10425954.

[37]. Gulabivala K, Opasanon A, Ng YL, Alavi A. Root and canal morphology of Thai mandibular molars. Int Endod J. 2002 Jan; 35(1): 56-62. PMID: 11853239.

[38]. Martins JNR, Mata A, Marques D, Caramês J. Prevalence of C-shaped mandibular molars in the Portuguese population evaluated by cone-beam computed tomography. Eur J Dent. 2016 Oct-Dec; 10(4): 529-535. PMID: 28042270.

[39]. Zheng Q, Zhang L, Zhou X, Wang Q, Wang Y, Tang L, et al. C-shaped root canal system in mandibular second molars in a Chinese population evaluated by cone-beam computed tomography. Int Endod J. 2011 Sep; 44(9): 85762. PMID: 21599707.

[40]. Wadhwani S, Singh MP, Agarwal M, Somasundaram P, Rawtiya M, Wadhwani PK. Prevalence of C-shaped canals in mandibular second and third molars in a central India population: A cone beam computed tomography analysis. J Conserv Dent. 2017 Sep-Oct; 20(5): 351-354. PMID: 29386785. 